\title{
International Conference on Language, Literature \& Culture Traces of Multiculturalism
}

Jana Bujnáková - Hana Hrancová (Brno)

$\mathrm{V}$ dňoch 19. - 20. 5. 2017 sa $\mathrm{v}$ druhom najväčšom litovskom meste Kaunas uskutočnil už 6. ročník medzinárodnej konferencie jazyka, literatúry a kultúry Traces of Multiculturalism. Konferenciu organizovali turecké univerzity Cankaya University (Ankara) a Suleyman Demirel University (Isparta) v spolupráci s Vytautas Magnus University (Kaunas), na pôde ktorej toto medzinárodné stretnutie prebehlo. Konferencia hostila účastníkov $\mathrm{z}$ viacerých krajín. $\mathrm{V}$ rámci Európy bolo zastúpené Taliansko, Rumunsko, Polsko, Česko, Španielsko, Velká Británia, Lotyšsko, Ukrajina a Litva. Zúčastnili sa jej však aj hostia zo Spojených štátov, Brazílie, Izraela, Iraku, Líbye, Gruzínska, Indie a vel'ké zastúpenie príspevkov ako spoluorganizátor malo Turecko. Vzhl’adom k vel'kému počtu účastníkov z rôznych krajín, komunikačným jazykom bola angličtina. Prednášky, ktoré prezentovali klúčoví rečníci prebehli hned' po slávnostnom otvorení. Konferencia bola organizačne vel'mi dobre zvládnutá - okrem prezentácie mnohých podnetných príspevkov bol pre účastníkov pripravený bohatý sprievodný program, ako komentovaná prehliadka mesta, či večerná recepcia.

Celé stretnutie sa nieslo vo vel'mi priatel'skom duchu. Úvodná prednáška (Challenges of the Digital Culture - Language and the New Media) ponúkla nové pohlady na preberanú problematiku mediálnej lingvistiky a jazyka internetu. Vilmantė Liubinienè sa venovala digitálnej a vizuálnej kultúre, ktorej rozvoj podnecuje súčasná globálna situácia a jej rýchly vývoj. $\mathrm{V}$ analýze o transformácii jazyka pod vplyvom New Media v oblasti lingvistiky autorka hovorila o tzv. mediálnej lingvistike, jazyku internetu a o novom jazyku médií. Jej cielom bolo predstavit výzvy podmienené digitalizáciou kultúry, pričom poukázala na zmeny chápania textu ako takého. Termín „text“ v súčasnosti nezahŕňa len písaný jazyk, ale odkazuje na všetky formy vyjadrovania, ako sú písané slová, statické a pohyblivé obrázky aj zvuky.

Jednotlivé prezentácie poukázali na rozsiahlu šírku problematiky multikulturalizmu v rôznych spoločenských oblastiach a na vnímanie multikulturalizmu v jednotlivých národných literatúrach. Vyjadrením politických a jazykových záujmov anglického spisovatela Harolda Pintera stelesnených $\mathrm{v}$ jeho dramatických hrách sa zaoberala Paulina Mirowska vo svojom príspevku The Language of Power: Harold Pinter's Provocative Political Playwriting. $\mathrm{O}$ anglickej literatúre s dôrazom na tému domova a identity hovorila aj Sıla Şenlen Güvenç (Transnational Spaces and Cosmopolitan Identities in David Greig's Plays). Polskej národnej literatúre sa venovali Paweł Kaptur (Traces of Polishness in Cromwellian and Restoration England), Aleksandra Niemirycz (What does a Tyrannosaurus like? Barbara Sadowska's Poetry and Aesopian Language of Poets in the Collapsing World on Both Sides of the Iron Curtain) a Anne Marie Novak (The Dybbuks of Polish Literature and Film), ktorá skúmala prelínajúcu sa históriu židovskej a pol’skej literatúry.

Prvky multikulturalizmu v sci-fi literatúre skúmali Adelheid Rundholz-Eubanks (Zombies, Popular Culture and Crisis: Dissecting Homogeneity through Horror Cinema) a Emilis Kasparas (On Science Fiction and Exile). Príspevok Ireny Ragaišienè a Audronė Raškauskienè vychádzal z výskumného projektu BYLEC (Baltic Young Learners of English Corpus). Analýza sa zameriavala na skúmanie spoločenských a rodinných hodnôt mladých študentov angličtiny. Predmet výskumu bol postavený na ich predstavách v súvislosti s budúcou rodinou a domovom.

Silné zastúpenie mala jazyková oblast', bádalo sa o teórii prekladu v prezentácii Marie Cândida Figueiredo Moura (The Untranslatability of 
Folkloric Cakes on the Dicionário do Folclore Brasileiro by Câmara Cascudo: a Proposal of Ethnographic Translation) a Mohameda M. Benotmana (Contrastive Analysis in Translation Equivalence). Natia Zviadadze a Ekaterine Archvadze sa zamerali na aplikáciu komunikačných aktivít vo výučbe jazykových systémov a zručností, s cielom dosiahnut požadovanú úroveň jazykových schopností žiakov. Cudzí jazyk ako prostriedok lepšieho preniknutia a pochopenia do kultúry iného národa analyzovali Nino Demetradze a Ekaterine Kurdadze (Communicative Approach: the Method and the Goal of Teaching).

Otázky multikulturalizmu sa najčastejšie rozoberali cez konkrétne významné literárne diela prezentované predstavitel'mi odlišných národností (Selin Yılmaz, Milda-Julija Danytè). Büşra Kırmızı sa venoval vplyvu vzdelávania na rôzne etniká. Na pozadí príspevku zdôrazňoval termín nadnárodnost', ktorá vytvára väčšiu mieru prepojenia jednotlivcov, rôznych spoločenstiev a spoločností a ich vzájomných vplyvov v sociálnej, kultúrnej, ekonomickej a politickej oblasti.

Viacerí účastníci poukázali na kontrast medzi arabskou a západnou civilizáciou v súvislosti s multikulturalizmom. Problém asimilácie arabskej ženy v britskom prostredí načrtol A. Nejat Töngür (Crosscultural Bridges and Transformation in Leila Aboulela'a The Translator). Ingrīda Kleinhofa (Arabs in Literature: Depictions by Arab Emigrant Writers for Insiders and Outsiders) porovnávala zobrazovanie Arabov, arabskými emigrantskými spisovatelmi odlišne pre domácich a západných čitatelov.

Sondou do komparatívnej analýzy multikultúrnych komunít sa v interpretácii Ishigurovho románu Hywel Dix odchyluje od určitého základného predpokladu o rase a etnickom pôvode. Tým je komplexné multikultúrne zloženie komunity, kde dielo vzniklo. Tvrdil, že Ishigurov protagonista môže byt v imperiálnom svete tridsiatych rokov Velkej Británie, interpretovaný ako koloniálne „iný“ v porovnaní s autorovým zobrazením. Ishiguro sám explicitne identifikuje postavy, ale zobrazenie postáv je skôr nástrojom interpretačných kompetencií, ktoré má každý čitatel’ iné, pretože má k dispozícii mnoho d'alších ovplyvňujúcich faktorov. Môže sa jednat o faktory jazykové, historické, kultúrne a porovnávacie. Ishigurove postavy teda sú predstavované ako členovia multikultúrnej spoločnosti, pretože autorove vlastné jazykové dedičstvo je vytvorené z kombinácií rôznych druhov súčasnej angličtiny, čo sa prenáša aj na jeho postavy.

$\mathrm{V}$ prezentovaných výskumoch sa často zobrazovala trauma ako neoddelitelný dôsledok multikulturalizmu. Na jej formu v amerických románoch poukázala Silvia Ammary (The Nature of Trauma in Modernist American Novels). Yıldıray Çevik rozoberala traumu afrických detí v krajinách postihnutých chudobou. Problematiku medzikultúrnej traumy v románe Salt to the Sea prezentovala Ingrida Žindžiuviené. Rozoberala čas a priestor v kolektívnej pamäti s dôrazom na základné otázky zohrávajúce klúčovú úlohu pri jej vytváraní a zachovávaní. Vychádzala z prejavov kolektívnej traumy a jej následného zakoreňovania sa do skupinových spomienok. Apelovala na pružnost’ a plynulost' kolektívnej pamäti, ktorá má byt podobná typom osobnej pamäti. Taktiež predostrela teóriu o rôznych typoch spomienok skúmaných z hladiska multikultúrnej kolektívnej traumy, pričom príklady prezentovala na uvedenom diele. Ústrednou témou je kultúrna trauma ako dôsledok druhej svetovej vojny z oblasti východnej Európy. Román je príkladom toho, ako fiktívny príbeh odohrávajúci sa na pozadí historických faktov zamestnáva kolektívnu pamät. Autorka zdôraznila blízky vztah medzi individuálnou a skupinovou pamätou, ktoré sa vzájomne výrazne ovplyvňujú.

Ştefan Lucian Mureşanu sa zameral na populárnu literatúru a antropologické postoje (The Eternal Cross and The Light of Crescent Moon, Medieval Waking of Faith in the Carolingian Period). Vel'kú úlohu pri formovaní stredovekej spoločnosti zohrávali vojny a intrigy, pretože ako autor prízvukuje - vo vtedajšej dobovej spoločnosti sa nekládol zásadný dôraz na diplomatické vztahy. Konflikty boli zdrojom intríg a neposlušnosti potulných hercov, ktorí na večierkoch prednášali vojnové básne, aby zabavili svojich pánov. Vojna sa tak stala hlavnou činnostou stredove- 
kých rytierov a šlachticov. Tí aj v období mieru trávili čas na turnajoch. V stredovekej literárnej tvorbe v období medzi 8. a 15. storočím tak nájdeme dva hlavné smery - literatúru vyjadrujúcu pojmy, ideály, chư feudálneho človeka k životu a literatúru vyjadrenú vo formách prijatých progresívnou triedou.

Olga Bogdanska poukázala na zaujímavý aspekt multikulturalizmu v príspevku o vojenskom festivale organizovanom v rámci medzinárodného kontextu. Stretnutie sa odohráva na Edinburghskom hrade od roku 1950 a postupne si získalo celosvetovú popularitu. Hlavným cielom je snaha armádnych predstavitelov priblížit sa verejnosti pripraveným programom. Festival je silným multikultúrnym zážitkom s účastou mnohých zahraničných hostí.

Konferencia pokryla širokú škálu rôznych tematických okruhov. Nosnou oblastou bola literatúra a multikultúrne interakcie prezentované na konkrétnych príkladoch. Medzinárodné stretnutie ocenili aj mnohí doktorandi, ktorí dostali možnost’ prezentovat svoje realizované výskumy.

Mgr. Jana Bujnáková / bujnak.jana@gmail.com

Mgr. Hana Hrancová / 450832@mail.muni.cz

Ústav slavistiky

Filozofická fakulta, Masarykova univerzita

Arna Nováka 1, 60200 Brno, Česká republika 